
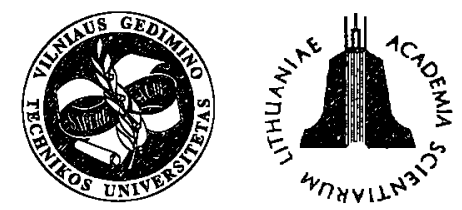

ISSN 1648-4142 TRANSPORT

http:/www.vtu.lt/english/editions

TRANSPORT - 2003, Vol XVIII, No 4, 143-152

\title{
TECHNICAL AND ECONOMICAL PROBLEMS OF INTEGRATION OF IX B AND XI D INTERNATIONAL RAILWAY TRANSPORT CORRIDORS INTO EUROPEAN RAILWAY TRANSPORT NETWORK
}

\author{
Laura Černiauskaité ${ }^{1}$, Kazys Sakalauskas ${ }^{2}$ \\ Dept of Roads, Vilnius Gediminas Technical University, \\ Sauletekioal.11,LT-2040Vilnius, Lithuania.1E-mail: laucer@ap.vtu.lt. ${ }^{2} E$-mail: kazsak@ap.vtu.lt \\ Received 200301 27; accepted 20030630
}

\begin{abstract}
Technical and economical problems of train speed increment up to $160 \mathrm{~km} / \mathrm{h}$ in existing IX B and IX D international railway transport corridors are analysed. Train speed restriction reasons, values of restrictions and their locations are estimated according to technical parameter characteristics of existing railway line infrastructure and according to the requirements for high-speed trains. The concept railway lines technical shape includes: plan, longitudinal profile, road upper construction and subgrade, besides quantitative and qualitative indices of elements. The most important indicator of railway lines technical shape is the permissible speed of trains. The radius of lying curves is taken as the most important investigation object in the analysis of geometry of railway lines plan. Computer programme "Trauka" ("Traction") is used for the solution of problems of train speed increase. The programme is intended to calculate train speed and train driving time by evaluating the technical level of existing railway lines infrastructure. Great attention is paid to a complex analysis of road plan, longitudinal profile and upper road structure elements when railway lincs infrastructure reconstruction is carried out. The application of these methods in practice allows the exact estimation of train speed increment possibilities when speed restriction reasons are eliminated.
\end{abstract}

Keywords: the AGC and AGTC agreements, technical level of infrastructure, traction calculation, speed restrictions, train speed, train driving time, plan curve.

\section{Introduction}

Present Lithuanian railway transport sector, as well as the one in most of the Eastern Europe countries, is rather behind the modern, sophisticated and reciprocal Western and Northern Europe railway transport systems, from technical, economical, technological and organizational point of view. To successfully integrate into European railway transport system extreme changes in Lithuanian railways are necessary.Especially the approach of the railway infrastructure to the technical level of railway network at European Union countries is needed.

While integrating Lithuanian railway network (IX B and IX D international railway transport corridor branches, passing Lithuanian territory) into the European Union transport system, parameters of infrastructural elements have to satisfy the requirements of the international agreements AGC and AGTC at first. Railroad construction elements and geometrical parameters have to be urgently regulated with the requirements of European transport network. Railway infrastructure technical level is a very important indicator in this process [1-2].
European countries have created "International Railway Network" according to the AGC protocol, confirmed in 1985 in Geneva. Following their own laws and possibilities, European countries have pledged to maintain and improve this network. Trunk-lines in the network are divided into two categories. $\mathrm{A}$ - main lines, where huge international loads are already shipped; B - secondary lines will complement existing railway network in the future and will improve shipment quality.

In the AGTC agreement, signed in 1991 in Geneva, it is indicated to provide railway network " $E$ " with multiplicity of equipment, which would ensure the process of international composite inter-modal shipment. Such shipment system enables to carry goods from door to door leastwise by two different kinds of transport. Generally this totality comprises large containers, exchangeable tankages and different vehicles to carry passengers.

According to the AGC and AGTC agreements it was concluded that seeking to unify railway lines infrastructure parameters in European countries, most parameters designed according to the requirements of these countries can remain. However, the ones belonging to 
the plan and longitudinal profile of the railway lines have to be adjusted. The most important infrastructural parameters according to the $A G C$ and $A G T C$ agreements are presented in Table 1 [3-6].

These requirements are applied for the modernization of lines, which are incorporated into Transport Infrastructure Needs Assessment (TINA) program. This incorporation was initiated by the European Union Committee in 1995. Infrastructure modernization projects TNA are presented in Fig 1.

The purpose of TINA is to estimate the needs of Middle and East Europe countries-candidates to the European Union and to identify projects of common interests [1].

These projects should initiate the development of multi-modal transport network between the European Union countries and countries-candidates to the European Union. Financing has to be scheduled as well.

TINA network includes underlying of I and IX international railway transport corridors that pass Lithuanian territory. According to TINA, during the modernization of the main railway lines it is necessary to follow the European Union directive 96/48/EB, defining transeuropean high-speed railways system interaction.

According to this directive the whole railway infrastructure and rolling-stock characteristics compatibility have to be insured in the whole transeuropean transport network (TEN-Tr).

Modernization of the infrastructure according to TINA projects is shown in Fig 1.

The AGC agreement recommends laying of only heat-treated rails $\mathrm{R} 65$ or rails type UIC 60 welded in the factories into links of 800 meters length.

Tilt of the rail in the riser is $1: 20$, when it is fixed with spring-loaded strainers.

Sleepers should be made of reinforced concrete and allocated in the straight line every $0,6 \mathrm{~m}$ and on the curves every $0,55 \mathrm{~m}$.

Breakstone bed thickness is $35-40 \mathrm{~cm}$, if the prism is double-layered, the thickness of the sand layer, which is below, is $25 \mathrm{~cm}$ and the thickness of the breakstone layer, which is above, is $20-30 \mathrm{~cm}$.

Prism arm is $40 \mathrm{~cm}$ and side inclination is $1: 1,5$. Width of the subgrade in the double-road railways should be $11,7 \mathrm{~m}$ (uppermost) and side inclination 1:1,5.

Density of the main $55 \mathrm{~cm}$ platform upper layer has to be not less than $1,65-2,0 \mathrm{~g} / \mathrm{cm}^{3}$ and permissible tension in the surface has to be $0,08-0,12 \mathrm{MPa}$.

Norms of permissible deviations of geometrical road parameters are noticeably toughened. Rail surface roughness should not be more than $0,5-0,7 \mathrm{~mm}$. Width of the tread has to differ from the standards not more than +5 and $-3 \mathrm{~mm}$ [5].

At the moment there are 220 kilometers of railroads in IX (B, D) transport corridor, which are renovated according to the requirements of the EU standards [1].

\section{Research of IX B and IX D International Trans- port Corridors Infrastructure}

The concept of railway lines technical shape includes: plan, longitudinal profile, road upper construction and subgrade, besides quantitative and qualitative indices of elements.

Table 1. According to the AGC and AGTC agreements the infrastructure of existing lines under modernization has to satisfy the following requirements

\begin{tabular}{|c|c|c|}
\hline \multirow[t]{2}{*}{ Infrastructural parameters } & \multicolumn{2}{|c|}{ Requirements } \\
\hline & $\mathrm{AGC}$ & AGTC \\
\hline Number of roads & 1 or 2 & not indicated \\
\hline Clearance of rolling-stock & UIC B & UIC B \\
\hline Minimal velocity, $\mathrm{km} / \mathrm{h}$ & 160 & 120 \\
\hline Distance between axes, $\mathrm{m}$ & 4 & 4 \\
\hline Permissible load to one linear meter, $\mathfrak{t}$ & 8 & not indicated \\
\hline \multicolumn{3}{|l|}{ Load to the axis: } \\
\hline Locomotives up to $200 \mathrm{~km} / \mathrm{h}$ & $22,5 \mathrm{t}$ & $22,5 \mathrm{t}$ \\
\hline Diesel and electric trains up to $300 \mathrm{~km} / \mathrm{h}$ & $17 \mathrm{t}$ & not indicated \\
\hline \multicolumn{3}{|l|}{ wagonloads: } \\
\hline up to $100 \mathrm{~km} / \mathrm{h}$ & $20 \mathrm{t}$ & $20 \mathrm{t}$ \\
\hline up to $120 \mathrm{~km} / \mathrm{h}$ & $20 t$ & $22.5 \mathrm{t}$ \\
\hline up to $140 \mathrm{~km} / \mathrm{h}$ & $18 \mathrm{t}$ & not indicated \\
\hline Maximum inclination, $\% o$ & inclination is formed & inclination is formed \\
\hline Minimal platform length in big stations, $\mathrm{m}$ & 400 & not indicated \\
\hline Minimal bypass length, $\mathrm{m}$ & 750 & 500 \\
\hline Crossings & not a single & not indicated \\
\hline
\end{tabular}




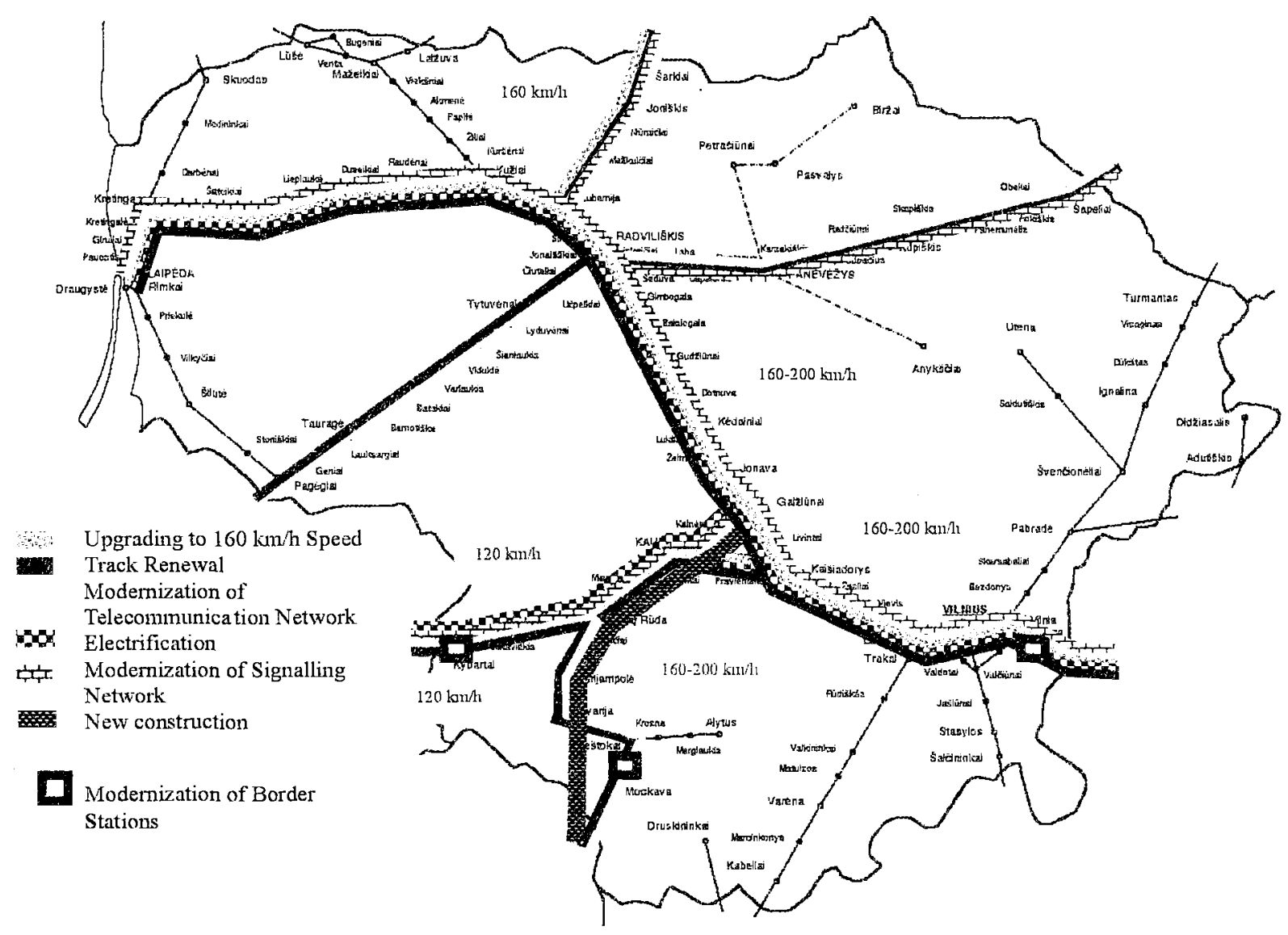

Fig 1. Infrastructure of modernization projects - TINA

The permissible speed of trains is the most important indicator of railway lines technical shape.

The main object of the research is IX international railway transport corridor. Two branches crossing Lithuanian territory, i. e. IX B corridor branch VilniusKlaipeda and the IX D corridor branch KaišiadorysKybartai are analysed.

In the analysis the plan geometry of railway lines, the most meaningful elements (such as plan curves, external rail platform, conversion curves) for train speed are accentuated. Train speed is regulated by plan curves of small radius [6-7], by length of conversion curves and by dimensioning the platform.

During the analysis the upper road structure is subdivided into elements: rails, sleepers, ballast, switches and subgrade. All the elements are analysed and evaluated separately and only afterwards they are joined into one structure, so that it was possible to evaluate the deviation from a design level.

The condition of railway lines according to rail type can be evaluated as a good one, because passenger trains can speed up to $160 \mathrm{~km} / \mathrm{h}$ when rails are of UIC60 type or heavier. The situation is worse taking into consider- ation the calculated rail head wear. According to theoretical calculations it is estimated that train speed is influenced when railhead calculated wear is more than 9 mm [8]. Summarized research data results are presented in Fig 2.

The type of sleepers and their distribution do not make great influence on train speed. However, during research sleepers with defects were calculated apiece. After the research it was estimated that there were 1100 units of reinforced concrete sleepers with defect and 39280 units of inadequate wooden sleepers. It is not a good indicator because in the zones of old wooden sleepers (when there are several inappropriate sleepers consecutively) the train speed is limited. Detailed research results describing rail types are presented in Fig 3.

Type of the switches must be R65 or UIC60, 1/11 or $1 / 18$ crosspiece mark on the wooden or reinforced concrete switch sleepers with elastic spikes and crosspiece with mobile core [5].

Ballast is analysed according to its type and pollution. Pollution is measured by the amount of pollutants (in percent) in the total mass of ballast prism. It is estimated that ballast is breakstone, which is not a holdback 
for high-speed trains. However $389,5 \mathrm{~km}$ of the ballast is polluted by various pollutants and pollution is over $20 \%$, i.e. more than allowable.

Subgrade, as a part of railroad structure, is a support for upper railroad elements. Upper railroad structure strength depends on the subgrade quality. Subgrade is bulked or excavated during railroad construction. Its repair or qualitative improvement can be done only during major repairs, when the train traffic is prohibited.

The research of subgrade and its deformation is carried out according to geometric measurements of fillings or pit and geotechnical research. It is estimated that $34,9 \mathrm{~km}$ have various subgrade deformations.

It is necessary to carry out detailed engineering geological research of the subgrade and its intersection with various types of piping before increasing train speed in the maintained railway lines. The following subgrade deformations must be eliminated at first: risings, pits, ballast pits (shape of chamfer, den or nest), slide of mound and pit slopes, landslides and washouts.

Summarized parameter research data of IX B and IX D international transport corridors (railway lines Vilnius - Klaipeda and Kaišiadorys - Kybartai) infrastructure are presented in Tables 2 and 3.

\section{Research of the Dependence of the Railway Lines Infrastructure Parameters on the Train Speed}

During the infrastructural parameter analysis it was estimated that particular railroad sections do not satisfy the requirements, when freight train velocity is $120 \mathrm{~km} / \mathrm{h}$ and passenger train velocity is $160 \mathrm{~km} / \mathrm{h}$. Besides, most of the sections, where train speed is limited, have to be isolated. When they are joined into one complex, their effect changes a lot.

During the reconstruction of existing railway lines analytical methods are used to estimate train speed, driving time, different road maintenance indicators and influence of plan, longitudinal profile and elements technical shape of upper road structure (rails, sleepers, ballast, switches and subgrade) on train speed [9-12].

When solving train speed increment problems traction calculation method is the most commonly used in the whole world $[6,9-12]$. Great importance of traction calculation is attached to the reconstruction and maintenance of railway lines. For calculation of traction it is necessary to store a lot of data about technical parameters of railway infrastructure and about technical characteristics of locomotives and wagons. Their interrela-

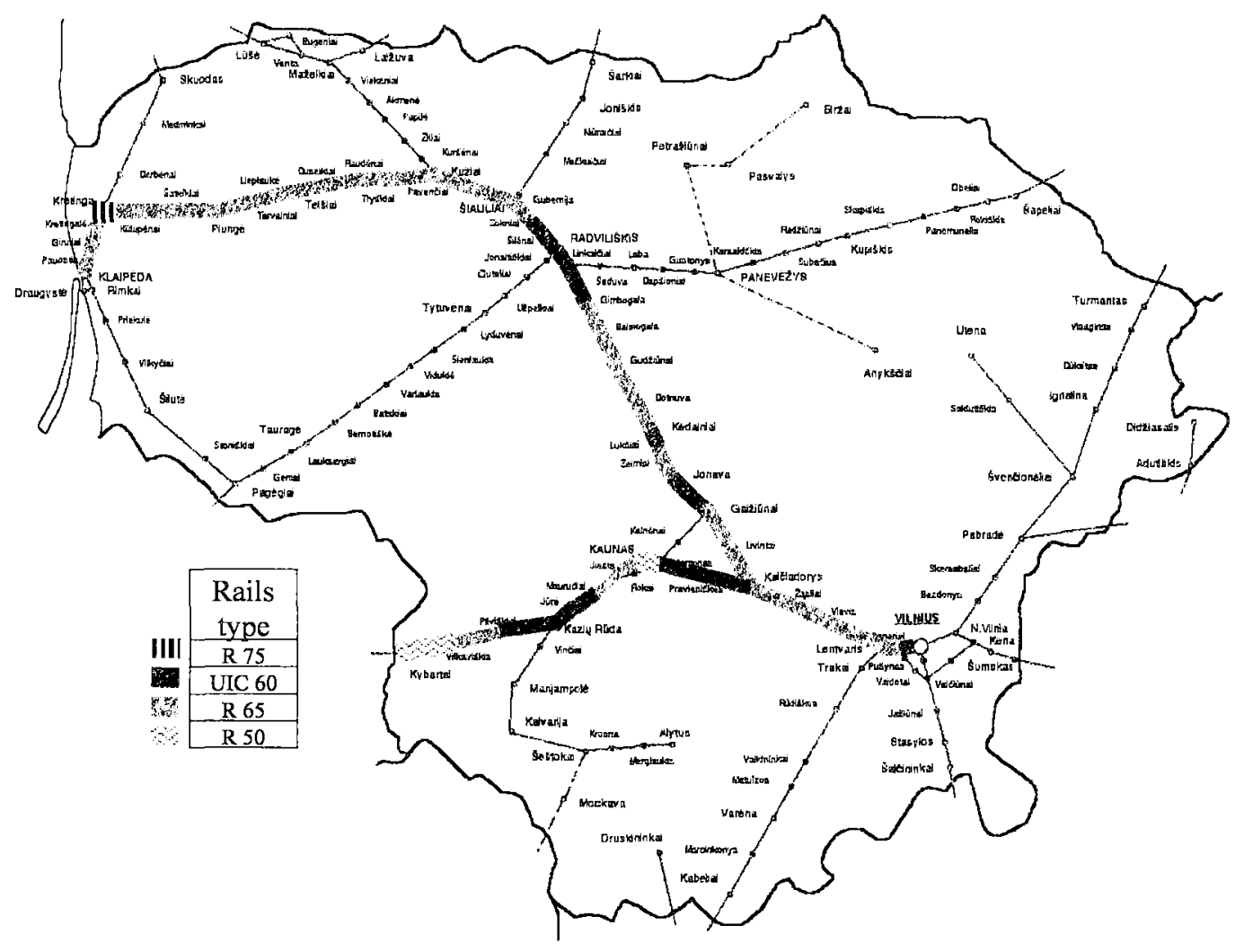

Fig 2. Rail types and rail wearing in IX B and IX D international transport corridors in Lithuanian railways lines 


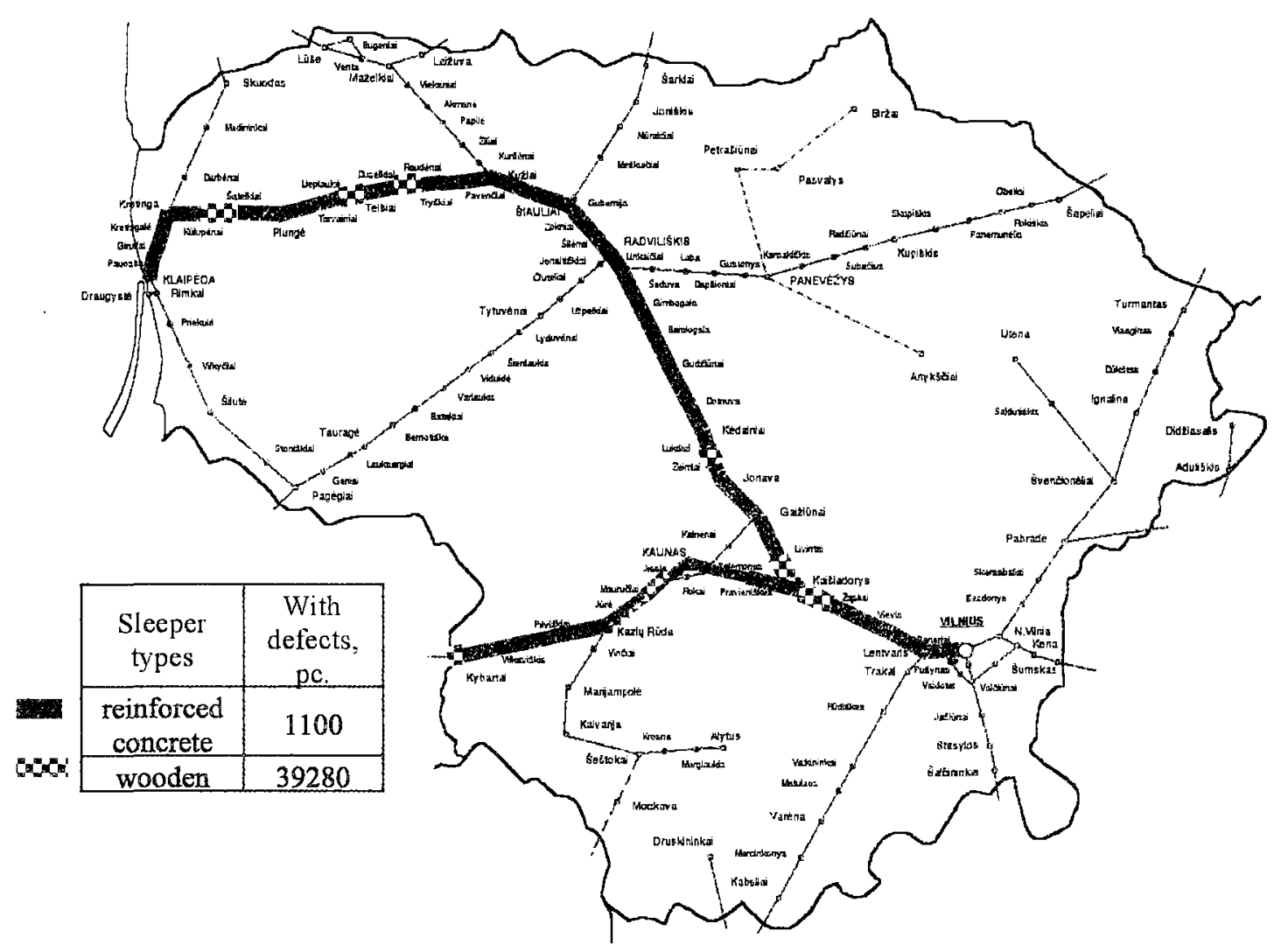

Fig 3. Sleeper types in IX B and IX D international transport corridors in Lithuanian railway lines

Table 2. Technical parameter summary according to spread out length of roads I and II of railway line Vilnius-Klaipèda

\begin{tabular}{|c|c|c|c|c|c|}
\hline No & Parameters & \multicolumn{4}{|c|}{ Values of parameters } \\
\hline \multirow{2}{*}{1} & \multirow{2}{*}{$\begin{array}{l}\text { Length of sections with appropriate } \\
\text { longitudinal inclination, km }\end{array}$} & $0 \%$ & $\leq 4 \%$ & $4,1-8 \%$ & $8,1-15 \%$ \\
\hline & & 81,5 & 343,2 & 151,4 & 26,7 \\
\hline \multirow{2}{*}{2} & \multirow{2}{*}{$\begin{array}{l}\text { Length of curved sections, } \mathrm{km} \text {, when } \\
\text { radius of plan curve is } \mathrm{R}, \mathrm{m}\end{array}$} & $\leq 650$ & $651-1000$ & $1001-1200$ & $>1200$ \\
\hline & & 12,1 & 49,4 & 40,1 & 73,5 \\
\hline 3 & $\begin{array}{l}\text { Length of the road with deformed } \\
\text { subgrade, km }\end{array}$ & \multicolumn{4}{|c|}{32,5} \\
\hline 4 & Switches with crosspiece mark $1 / 9, \mathrm{pc}$. & \multicolumn{4}{|c|}{64} \\
\hline 5 & Polluted ballast $>20 \%, \mathrm{~km}$ & \multicolumn{4}{|c|}{196,2} \\
\hline \multirow{2}{*}{6} & \multirow{2}{*}{ Sleepers with defects, pc. } & \multicolumn{2}{|c|}{ Wooden } & \multicolumn{2}{|c|}{ Reinforced concrete } \\
\hline & & \multicolumn{2}{|c|}{29180} & \multicolumn{2}{|c|}{940} \\
\hline \multirow{2}{*}{7} & \multirow{2}{*}{ Rails, km } & \multicolumn{2}{|c|}{ R 50} & \multicolumn{2}{|c|}{ Length of all 9-12 $\mathrm{mm}$ worn rails } \\
\hline & & \multicolumn{2}{|c|}{16,8} & \multicolumn{2}{|c|}{34,2} \\
\hline
\end{tabular}


Table 3. Technical parameter summary according to spread out length of roads I and II of railway line Kaišiadorys-Kybartai

\begin{tabular}{|c|c|c|c|c|c|}
\hline No & Parameters & \multicolumn{4}{|c|}{ Values of parameters } \\
\hline \multirow{2}{*}{1} & \multirow{2}{*}{$\begin{array}{l}\text { Length of sections with appropriate } \\
\text { longitudinal inclination, } \mathrm{km}\end{array}$} & $0 \%$ & $\leq 4 \%$ & $4,1-8 \% 0$ & $8,1-15 \%$ \\
\hline & & 42,1 & 135,8 & 71,4 & - \\
\hline \multirow{2}{*}{2} & \multirow{2}{*}{$\begin{array}{l}\text { Length of curved sections, km, when } \\
\text { radius of plan curve is } R, m\end{array}$} & $\leq 650$ & $651-1000$ & $1001-1200$ & $>1200$ \\
\hline & & 1,9 & 12,6 & 5,0 & 25,5 \\
\hline 3 & $\begin{array}{l}\text { Length of the road with deformed } \\
\text { subgrade, } \mathrm{km}\end{array}$ & \multicolumn{4}{|c|}{2,4} \\
\hline 4 & Switches with crosspiece mark $1 / 9, \mathrm{pc}$. & \multicolumn{4}{|c|}{35} \\
\hline 5 & Polluted ballast $>20 \%, \mathrm{~km}$ & \multicolumn{4}{|c|}{193,3} \\
\hline \multirow{2}{*}{6} & \multirow{2}{*}{ Sleepers with defects, pc. } & \multicolumn{2}{|c|}{ Wooden } & \multicolumn{2}{|c|}{ Reinforced concrete } \\
\hline & & \multicolumn{2}{|c|}{10100} & \multicolumn{2}{|c|}{160} \\
\hline \multirow{2}{*}{7} & \multirow{2}{*}{ Rails, km } & \multicolumn{2}{|c|}{ R 50} & \multicolumn{2}{|c|}{ Length of all $9-12 \mathrm{~mm}$ worn rails } \\
\hline & & \multicolumn{2}{|c|}{76,8} & \multicolumn{2}{|c|}{ - } \\
\hline
\end{tabular}

tion has to be estimated and related with train driving conditions. Big volume calculations are done using computer programs, which are made according to algorithms having a set of variables interrelated by integral equation of train movement $[6,10]$.

A computer program "Trauka" ("Traction") is used for the research. It is applied calculating train speed and driving time (when road plan and longitudinal profile, number of train stops, mass of the train, type of wagons, series of locomotive, factors restricting train going speed, places of train speed limitations and train going speed are known) [6].

A train is formed according to the requirements of AGC main international railway lines infrastructure object technical characteristics. All of the train speed research variants are analyzed according to thermal traction. As there is no electric traction in IX B and IX D international transport corridors passing Lithuanian territory (except Vilnius - Kaunas), variants with electric traction are not analyzed. Besides, according to foreign countries experience, to implement velocities up to 160 $\mathrm{km} / \mathrm{h}$ in exploitable lines, thermal traction is enough. According to AGC agreement requirements, five variants are picked for the research with a computer program "Trauka":

Variant I. 10 wagon passenger train and locomotive TEP70 are given. Constructive velocity of the locomotive is $160 \mathrm{~km} / \mathrm{h}$, mass of the train is $600 \mathrm{t}$. When time and velocity are calculated, lying curves, partitive points, switches and speed limitation in the inter-stations, caused by the present railroad technical condition are evaluated. The train is going from Vilnius to Klaipeda and it stops at the interjacent stations in Kaišiadorys and Šiauliai; also from Kaišiadorys to Kybartai and stops at the interjacent station in Kaunas. Train stationary time at the stations is not evaluated.

Variant II. 7 wagon passenger train and locomotive TEP70 are given. Constructive velocity of the loco- motive is $160 \mathrm{~km} / \mathrm{h}$, mass of the train is $420 \mathrm{t}$. When time and velocity are calculated, lying curves, partitive points, switches and speed limitation in the inter-stations, caused by the present railroad technical condition are evaluated. The train is going from Vilnius to Klaipeda and it stops at the interjacent stations in Kaišiadorys and Šiauliai; also from Kaišiadorys to Kybartai and stops at the interjacent station in Kaunas. Train stationary time at the stations is not evaluated.

Variant III. 10 wagon passenger train and locomotive TEP70 are given. Constructive velocity of the locomotive is $160 \mathrm{~km} / \mathrm{h}$, mass of the train is $600 \mathrm{t}$. When time and velocity are calculated, locomotive traction force, as well as speed and time limiting factors under consideration are maximally availed. At the stations train velocity is limited to $100 \mathrm{~km} / \mathrm{h}$. The train is going from Vilnius to Klaipeda and it stops at the interjacent stations in Kaišiadorys and Šiauliai; also from Kaišiadorys to Kybartai and stops at the interjacent station in Kaunas. Train stationary time at the stations is not evaluated.

Variant IV. 7 wagon passenger train and locomotive TEP70 are given. Constructive velocity of the locomotive is $160 \mathrm{~km} / \mathrm{h}$, mass of the train is $420 \mathrm{t}$. When time and velocity are calculated, locomotive traction force as well as speed and time limiting factors under consideration are maximally availed. At the stations train velocity is limited to $100 \mathrm{~km} / \mathrm{h}$. The train is going from Vilnius to Klaipeda and it stops at the interjacent stations in Kaišiadorys and Šiauliai; also from Kaišiadorys to Kybartai and stops at the interjacent station in Kaunas. Train stationary time at the stations is not evaluated.

Variant V. 7 wagon passenger train and locomotive TEP70 are given. Constructive velocity of the locomotive is $160 \mathrm{~km} / \mathrm{h}$, mass of the train is $420 \mathrm{t}$. When time and velocity are calculated, locomotive traction force as well as speed and time limiting factors under consideration are maximally availed. At Lentvaris, Kaišiadorys, Linkaičiai, Radviliškis, Šiauliai, Pauostis and Kaunas 
Table 4. Detailed traction calculation results estimated analysing line "Vilnius - Klaipeda"

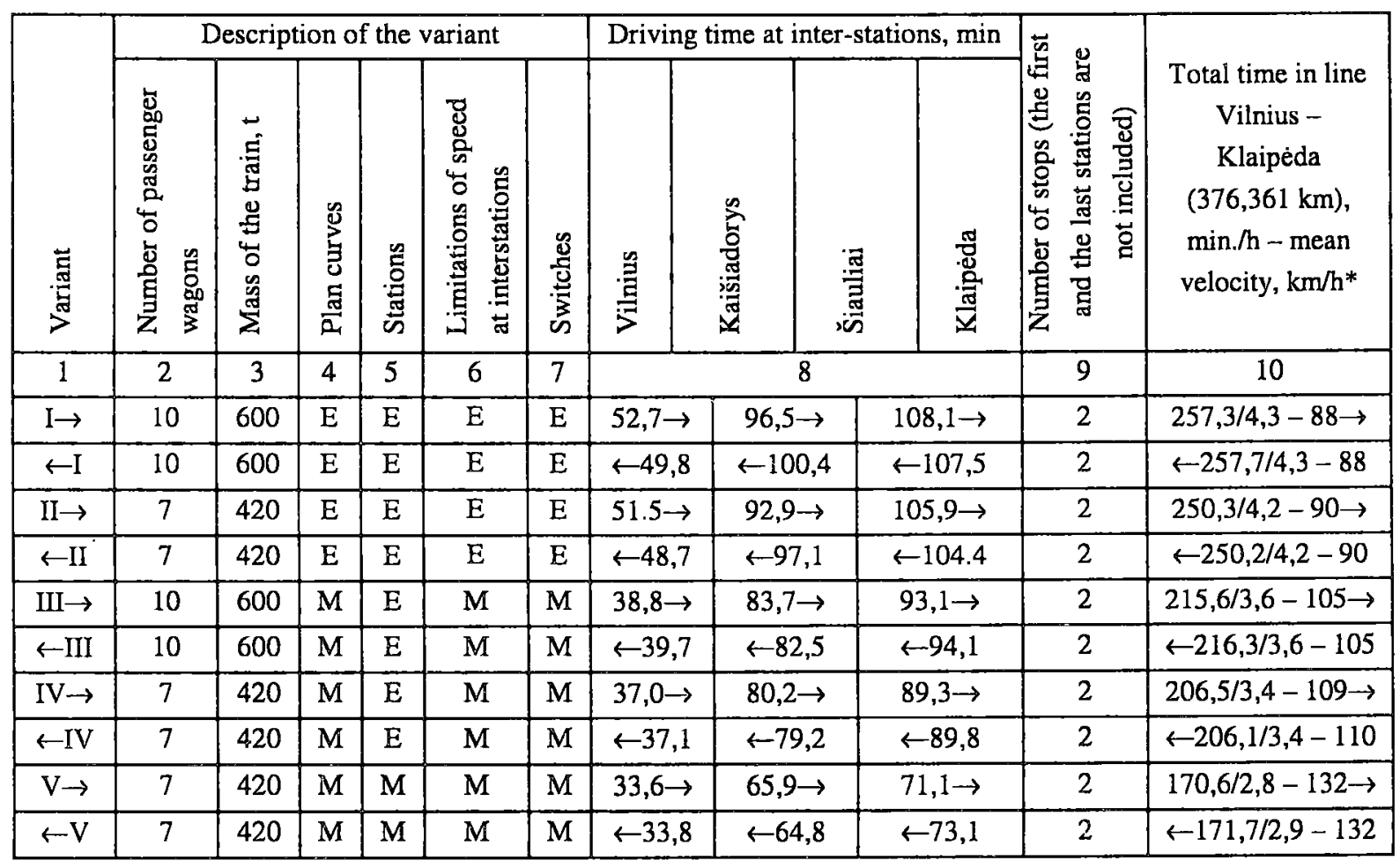

Table 5. Detailed traction calculation results estimated analysing line "Kaišiadorys-Kybartai"

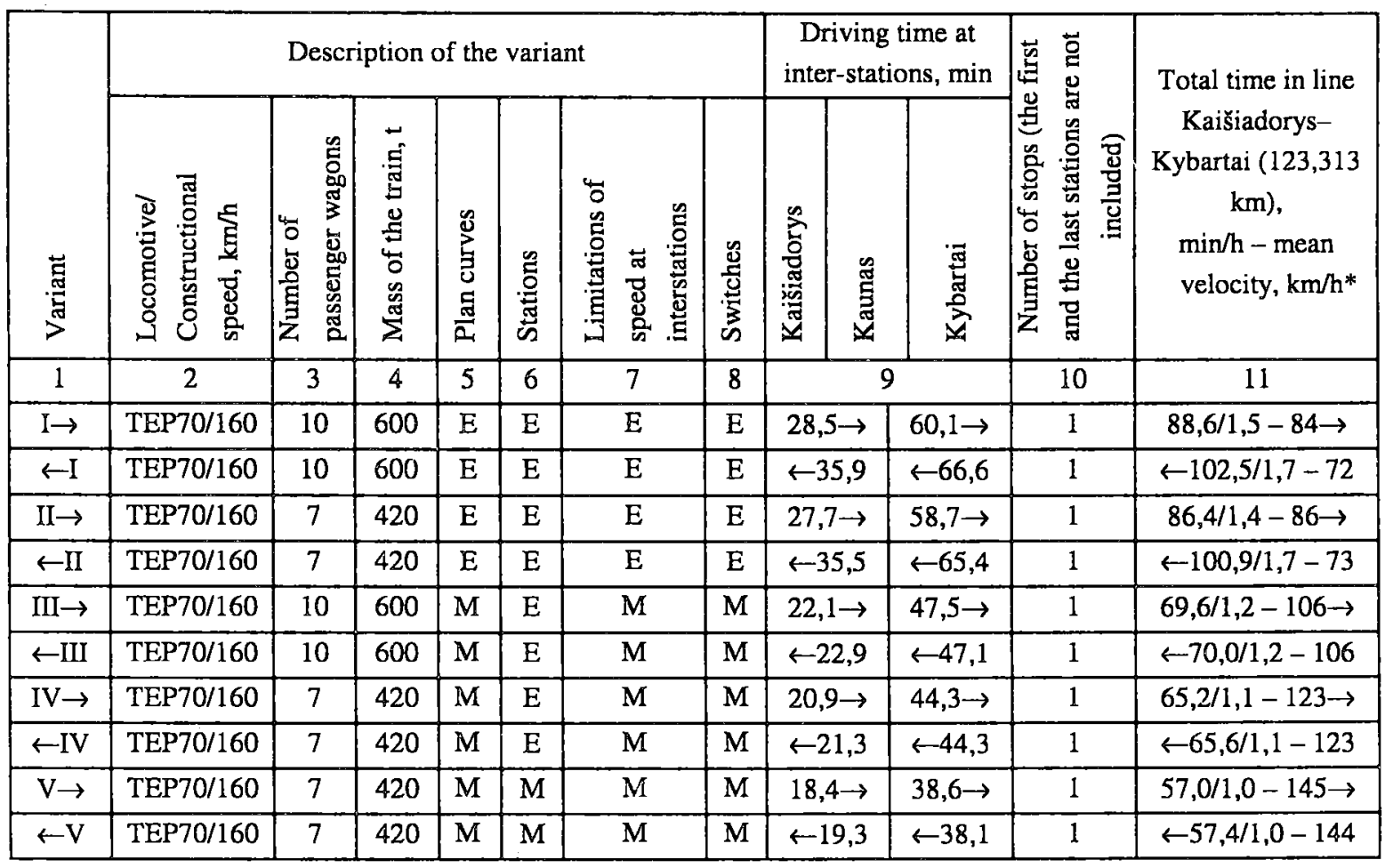

Note: $\rightarrow$ - train driving time is calculated in odd (forward) direction; $\leftarrow-$ train driving time is calculated in even (backward) direction; * - train stopping time is not evaluated; $M$ - plan curves of small radius, interstation speed restrictions are eliminated, switch guiding limiting speed is changed while carrying out traction calculation (see 5, 6, 7, 8 columns in Table); $\mathrm{E}$ - plan curves of small radius, stations, interstation speed restrictions, switch guiding is evaluated while carrying out traction calculation ( see 5 , $6,7,8$ columns in the Table). 
stations train velocity is limited to $100 \mathrm{~km} / \mathrm{h}$. The train is going from Vilnius to Klaipeda and it stops at the interjacent stations in Kaišiadorys and Šiauliai; also from Kaišiadorys to Kybartai and stops at the interjacent station in Kaunas. Train stationary time at the stations is not evaluated.

The description of the analysed variants carried out with program "Trauka" is presented in Tables 4 and 5. Graphical representations of variant II and V are shown in Fig 4. Train speed dependence on road state $v=f(s)$ is shown in the graph.

The detailed analysis of II and V traction calculation variants allows to estimate factors of train speed restrictions and their values, maximum train driving time decrease, average and maximum train going speed in separate road sections and throughout the line.

In the presented speed graph it is seen that sections of road where train may develop maximum speed of 160 $\mathrm{km} / \mathrm{h}$ are sufficient, when all speed restrictions factors are eliminated.

In the line Kaišiadorys-Kybartai only 7 plan curves of small radius that restrict train speed were estimated according to traction calculation variant II.

Maximum train driving time decrease $\Delta t$, min is 43,5 minutes. It is estimated comparing II and V traction calculation variants when train driving direction is even.

\section{Method of Calculating Train Driving Time and Mechanical Work Losses in Lying Curves of Small Radius}

In the plane of lying curves of small radius, high speed trains velocity before the curve and on the curve has to be decreased. This reason causes additional expenses for road maintenance and the increase of scope of mechanical work. To increase train speed it is necessary to increase radii of some lying curves. Such curve reconstruction requires quite huge expenses. Variant compari- son mathematical methods can help estimate when it is purposeful to start reconstruction and what sum of money is purposeful to invest. According to logical principle, purposeful sum of money to invest for the reconstruction of a curve, is the one that accumulates because of the increase of maintenance expenses during the calculating period, while trains decrease speed entering plane curve of small radius. Mathematically balance of expenses $\Delta A$, Lt can be expressed as [13]:

$$
\Delta A=\sum_{1}^{t} \frac{\Delta E_{t}}{(1+\eta)^{t}}
$$

where: $\Delta E_{t}$ - difference of yearly maintenance expenses before and after reconstruction, $\mathrm{Lt} ; \boldsymbol{\eta}$ - discount norm, estimating $10 \% ; t$-duration of reconstruction, $\mathrm{m}$.

To estimate time losses the following formula is suggested:

$$
\begin{aligned}
& \Delta t=0,5 \frac{v_{t}^{2}-v_{k}^{2}}{\left(f_{s}+\omega_{o}\right)_{v i d} \pm i}+{ }_{v_{k}}^{60}\left(k+l_{t}\right)+ \\
& v_{t}^{2}-v_{k}^{2} \\
& \left(f_{t}-\omega_{o}\right)_{v i d} \pm i
\end{aligned}
$$

where: $v_{t}$ - train velocity in the straight line, $\mathrm{km} / \mathrm{h} ; v_{k}-$ train velocity on the curve, $\mathrm{km} / \mathrm{h} ; f_{s}$ - relative braking force, $\mathrm{N} / \mathrm{kN} ; \omega_{o}$ - relative resistance, $\mathrm{N} / \mathrm{kN} ; k$ - length of lying curve in the plane, $\mathrm{m} ; l_{t}$ - length of the train, $\mathrm{m} ; f_{t}-$ relative traction force, $\mathrm{N} / \mathrm{kN} ; i$ - inclination of the road section under consideration, \%; $t_{t}$ - train driving time, when train is not braking on the curve, in the road section with limited velocity, min.

Losses of mechanical work appear on the curves of small radius, which restrict train speed, when the train has to decrease velocity before the curve and to increase it again when the curve is passed.

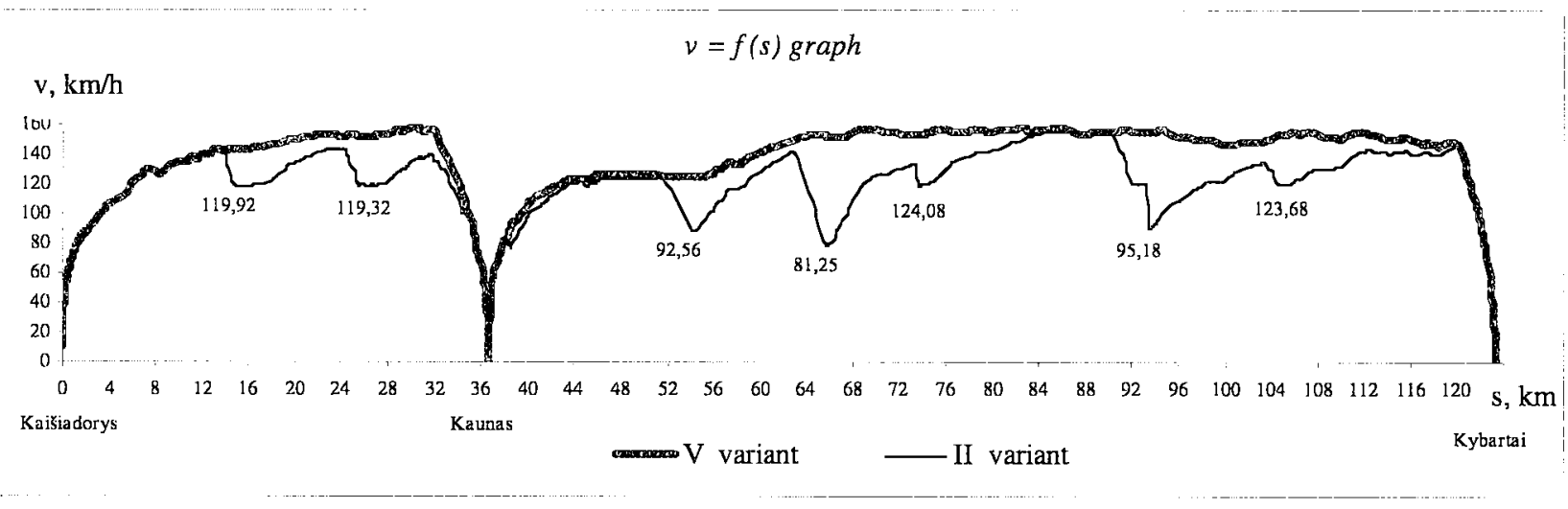

Fig 4. Comparison of speed graphs $v=f(s)$, when $v$ - train going speed, $\mathrm{km} / \mathrm{h}, s$ - railroad plan, longitudinal profil parameters and technical state, $\mathrm{km}$ of the II and V traction calculation variants in railway line Kaišiadorys-Kybartai (when train driving direction is odd) 
Losses of mechanical work $\Delta M$, tkm in the road section with limited speed, can be calculated according to the following formula:

$$
\begin{aligned}
& \Delta M=(P+Q)_{g} \times\left[4,17 \times\left(v_{t}^{2}-v_{k}^{2}\right)+\right. \\
& \left(\omega_{o} \pm i\right)_{s} \times S_{s}+\left(\omega_{o} \pm i\right)_{k} \times S_{k}+ \\
& \left.\left(\omega_{o} \pm i\right)_{g} \times S_{g}-\left(\omega_{o} \pm i\right)_{v i d} S_{r}\right] \times 10^{-6} ;
\end{aligned}
$$

where: $P$-mass of locomotive, $\mathrm{t} ; Q$ - mass of the train, $\mathrm{t} ;\left(\omega_{o} \pm i\right)_{\mathrm{s}}-$ mean relative train resistance, when train speed is decreased, $\mathrm{N} / \mathrm{kN} ;\left(\omega_{o} \pm i\right)_{\mathbf{k}}$ - mean relative train resistance on the curve, $\mathrm{N} / \mathrm{kN} ;\left(\omega_{o} \pm i\right)_{\mathrm{g}}-$ mean relative train resistance, when train speed is increased, $\mathrm{N} / \mathrm{kN} ;\left(\omega_{0}\right.$ $\pm i)_{\text {vid }}$ - mean relative train resistance in the hole road section with limited velocity, N/kN; $g$ - free fall acceleration, $\mathrm{m} / \mathrm{s}^{2}$.

When the intensity of traffic is known and losses of driving time and mechanical work of one train are calculated, total yearly traffic maintenance expenses $\Delta E_{m}, \mathrm{Lt}$ on the curve, which restrict speed, can be obtained according to the following formula:

$$
\Delta E_{m}=\left(60 \Delta t e_{t}+360 \Delta M e_{m}\right) n ;
$$

where: $e_{t}$-valuation of train one working hour, $\mathrm{Lt} ; e_{m}-$ valuation of one tkm, Lt; $n$ - quantity of trains with speed restricted by curve, during 24 hours.

Not only traffic maintenance expenses accumulate on the curves of small radius. As road supervision price exceeds and railway lines become longer, additional yearly expenses $\Delta E_{p}$, Lt accumulate as well. They can be calculated as follows:

$$
\begin{aligned}
\Delta E_{p} & =\frac{\Delta l}{1000} e_{k}+0,18(700-20 G) ; \\
\Delta E_{k} & =\Delta E_{m}+\Delta E_{p} .
\end{aligned}
$$

Expenses necessary for curve reconstruction are estimated according to individually prepared projects. However, when reconstruction accomplishment indicators are reliable, expenses necessary for curve reconstruction $\triangle A$, can be calculated as follows:

$$
\Delta A=B a_{\check{Z}}+L_{r} a_{\nu}-\Delta l a_{p} .
$$

where: $B$ - quantity of earthwork, $\mathrm{m}^{3} ; a_{\check{z}}$ - valuation of one earthwork unit, Lt; $L_{r}$ - length of the section under reconstruction, $\mathrm{m} ; a_{y}$-valuation of $1 \mathrm{~m}$ road upper construction, $\mathrm{Lt} ; l$ - shortening of track in the curve of larger radius, $\mathrm{m} ; a_{p}$ - valuation of $1 \mathrm{~m}$ road construction laying, Lt.

Amount of building expenses $\Delta A$ and beginning of reconstruction period $t$ will be rational only when balance in the formula (1) is settled.

\section{Conclusions}

1. From the very beginning of Lithuania's independence re-creation image of Lithuania was formed as a transit country joining Eastern and Western, Southern and Northern countries by international transport corridors. A very important factor seeking to assure passenger train speed of $160 \mathrm{~km} / \mathrm{h}$ is technical, technological and organisational development of the main Lithuanian railway lines infrastructure according to standards of the European Union.

2. Primary analysis has proved that estimating maximum train speed of $160 \mathrm{~km} / \mathrm{h}$, speed is markedly limited by the plan of the main lines, longitudinal profile, constant and permanent speed restrictions because of technical road and structure conditions.

3. Road plan and longitudinal profile elements geometry has been designed many decades ago and does not satisfy the requirements for high-speed passenger trains of the present time. This problem is not just technical, but economical as well, because the main obstacles for train speed increment is the enlargement of plan curves radius which is very expensive and technically complicated.

4. For increasing train speed it is necessary to strengthen the upper road construction, to decrease the number of switches on the main roads, to change schemes of station roads. It is necessary to eliminate subgrade deformations, to carry out special geological research and to prepare projects for subgrade reconstruction. Road structures strengthening is necessary as well.

5. Computer program "Trauka" ("Traction") is used for train speed increment problems solution. During the research into train speeds, speed restrictions and their values depending on the infrastructure of technical shape were estimated. The comparison of existing railway lines technical condition variants I and II and variants III, IV and $\mathrm{V}$, where train speed limitation number is decreased (plan curves of small radius, influence of distinctive stations and switches, speed restrictions because of upper road structure were eliminated) was done. During the comparison maximum train driving time decrease $\Delta t$ equal to 79,7 minutes (IX B) and 43,5 minutes (IX D) was estimated.

6. The suggested methodology for the calculation of lying curves of small radius train driving time and mechanical work losses is streamlined, but it suits to define the expedience for the reconstruction of curves.

7. It will be possible to evaluate capital investments for road plan, longitudinal profile, road structures and upper road structure elements reconstruction seeking to increase train speed if such a selection of variants will be done in further proceeding. 


\section{References}

1. Trumpa, V. S. Transport corridors and the perspectives of their development. Lithuanian railways (Lietuvos geležinkeliai), No 1, 2002, p. 16-22 (in Lithuanian).

2. Lingaitis, L. P. The future of railways. Lithuanian railways (Lietuvos geležinkeliai), No 1, 2002, p. 56-61 (in Lithuanian).

3. Sadovski, S. Modernization of railway line E20: Kunovuce Poznan-Warsaw-Minsk-Mazovecki-Terespol. OSZD bulletin (Модернизация железнодорожной линии Е20 Куновуце-Познань-Варшава-Минск-МазовецкиТересполь. Бюллетень ОСЖД), No 6. Moscow, 2001, p. 25-28 (in Russian).

4. Eurailspeed 98. 3rd World Congress on high-speed Rail. In: Congress proceedings, Vol 1, France. 1998-09/10. 324 p.

5. European railway technical harmonisation. UTC East-West Task Force Policy Paper. In: UIC-East-West Division, 1999 $6 \mathrm{p}$.

6. Sakalauskas, K. Rezgaitis, R. Problems and perspectives of traffic of high-speed passenger trains. Transport Engineering (Transportas), Vol XV, No 5. Vilnius: Technika, 2000 , p. 244-256 (in Lithuanian).

7. Sakalauskas, K. Influence of standard development in railway line design on train speed. Transport Engineering (Transportas), Vol XVI, No 5. Vilnius: Technika, 2001, p. 191-195 (in Lithuanian).
8. Sakalauskas, K. Problems of designing geometry and structure of high-speed railways. Transport Engineering (Transportas), No 1(14). Vilnius: Technika, 1997, p. 35-38 (in Lithuanian).

9. Bałuch, M. Testing possibilities of increasing speed of selected trains on the route Warszawa-Poznań. The Works Railway Scientific and Technical Centre (PRACE Centrum Naukowo-Technicznego Kolejnictwa). No 137. Warszawa. 2002, p. 11-19 (in Polish).

10. Bazaras, Ž.; Ivaškevičius, A.; Keršys, R. Calculation optimization of locomotive traction. Transport Engineering (Transportas), Vol XIII, No 4. Vilnius: Technika, 1998, p. 146-157 (in Lithuanian)

11. Koc, W. Analysis of limited train speed in railway line curves. In: IX Scientific-Technical conference. Cracow railroads (IX Konferencja Naukowo-Techniczna Drogi Kolejowe). Krakow, 1997, p. 111-121 (in Polish).

12. Pevzner, V. O. Selection of rational train speed. Railway transport (Железнодорожный транспорт), No 3. Moscow, 2000 , p. $47-53$ (in Russian).

13. Sakalauskas, K. Estimation of feasibility of reconstructing of railroad plan curves. Transport Engineering (Transportas), Vol XIII, No 1. Vilnius: Technika, 1998, p. 40-42 (in Lithuanian). 